\title{
ANALISIS UPAYA STRATEGI PEMASARAN DINAS KOPERASI USAHA KECIL MENENGAH DAN PERDAGANGAN KOTA PEMATANGSIANTAR DALAM MENINGKATKAN HASIL PENJUALAN PRODUK UKM TENUN ULOS DI KOTA PEMATANGSIANTAR
}

\author{
${ }^{1}$ Idia Fhitri Syawalina, ${ }^{2}$ Ahnis Zulkarnain, ${ }^{3}$ Muhammad Zufri, ${ }^{4}$ Pipfhan Syahuri Srg, ${ }^{5}$ Fahry Alamsyah \\ $1,2,3,4,5$ Universitas Islam Sumatera Utara \\ İdia.fhtri@gmail.com, ${ }^{2}$ ahnis.zulkarnain@gmail.com, ${ }^{3}$ mhd.zufri@gmail.com, ${ }^{4}$ Pipfhan.syahuri@gmail.colm, \\ ${ }^{5}$ fahry.alamsyah@gmail.com
}

\begin{abstract}
This research discusses about the influences of product, price, and promotion as marketing strategies in increasing sales volume of UKM product at Pematangsiantar City. The aim of this research is to analyse the influences of product, price, and promotion both partially and simultaneously on product sales volume at the office. This is a quantitative research with random sampling technique. The sample is 74 cosumers. Results show that each independent variable; product, price, and promotion, partially influences product sales volume positively and significantly. product has tcount value 6,853 and level of significance 0.000, price has 3,522 and 0.001, and promotion has 4,238 and 0.000. Simultaneously, product, price, and promotion have significant and positive influences in increasing sales volume of UKM product at Pematangsiantar City with Fcount value 64,813 and level of significance 0.000 .
\end{abstract}

Key words: product, price, promotion, sales volume, ulos.

\begin{abstract}
ABSTRAK : Penelitian ini membahas tentang bagaimana pengaruh produk, harga dan promosi terhadap hasil penjualan Dinas Koperasi, Usaha Kecil Menengah dan Perdagangan Kota Pematangsiantar. Penelitian ini bertujuan untuk menguji pengaruh produk, harga dan promosi baik secara partial maupun simultan terhadap hasil penjualan Dinas Koperasi Usaha Kecil Menengah dan Perdagangan Kota Pematangsiantar. Penelitian ini merupakan penelitian kuantitatif. Teknik penarikan sampel yang digunakan adalah total sampling dengan menggunakan sampel sebanyak 74 orang pegawai. Hasil penelitian menunjukkan bahwa variabel produk memiliki nilai thitung sebesar 6,853 dan signifikansi 0,000, variabel harga memiliki nilai thitung sebesar 4,233 dan signifikansi 0,001, dan promosi memiliki nilai thitung sebesar 3,559 dan signifikansi 0,000. Dengan demikian dapat dikatakan bahwa secara parsial masing-masing dari produk, harga dan promosi berpengaruh positif dan signifikan terhadap hasil penjualan. Secara simultan ketiga variabel tersebut juga berpengaruh positif dan signifikan terhadap hasil penjualan Dinas Koperasi Usaha Kecil Menengah dan Perdagangan Kota Pematangsiantar dengan nilai Fhitung sebesar 64,183 dan signifikansi 0,000.
\end{abstract}

Kata Kunci: produk, harga, promosi, hasil penjualan, pegawai

\section{Pendahuluan}

Suku Batak sudah mengenal Ulos sejak abad ke-14, bersamaan dengan masuknya alat tenun tangan dari India. Awalnya, Ulos berfungsi sebagai penghangat badan bagi nenek moyang suku Batak yang hidup di kawasan pegunungan. Ulos pun menjadi simbol kehangatan bagi suku Batak kala itu. Berdasarkan pandangan suku Batak, terdapat tiga unsur yang menjadi dasar dalam kehidupan manusia, yakni darah, napas, dan panas. Darah dan napas merupakan pemberian Tuhan, tapi tidak dengan unsur panas. Menurut suku Batak, panas matahari belum cukup untuk mengikis udara dingin. Alhasil, Ulos menjadi salah satu sumber panas bagi suku Batak, selain matahari dan api. Seiring waktu berjalan, Ulos bukan lagi sekadar kain penghangat tubuh. Ulos menjadi kain yang melambangkan ikatan kasih sayang antara orangtua dan anak-anaknya atau antara satu orang dengan orang lain. Makna tersebut sesuai dengan filsafat Batak, yakni "Ijuk pengihot ni hodong. Ulos penghit ni halong" yang berarti ijuk pengikat pelepah pada batangnya dan Ulos pengikat kasih sayang di antara sesame (Purba,1977).

Harga kain Tenun Ulos ini cukup mahal karen pembuatannya juga tidaklah mudah, butuh waktu 
lama dan kerumitan yang lumayan. Setiap tenunan yang dibuat juga mempunyai arti sendiri-sendiri. Pihak konsumen sekarang juga sudah banyak yang mengetahui tentang kain Ulos. Bahkan diluar negeri juga kain Ulos ini cukup dikenal, karena coraknya yang indah. Disamping mengenalkan kain tenun ini ke masyarakat dan mancanegara juga kita sama saja mengenalkan kebudayaan kita dan melestarikannya. Membuat bisnis ini mampu diterima di dunia bisnis.

Peningkatan industri Tenun Ulos baik yang dilakukan dengan skala kecil maupun besar tentunya harus dimulai dari pemasaran. Pemasaran dalam sebuah perusahaan memiliki peranan yang sangat penting. Pemasaran yang baik akan menentukan kesuksesan semua perusahaan. Tanpa adanya pemasaran, mustahil bagi sebuah perusahaan untuk dapat meneruskan kelangsungan usaha dan mencapai tujuannya. Pemasaran akan berhasil baik jika sebuah perusahaan mampu mengenal dan memahami apa yang menjadi kebutuhan dan keinginan pelanggan. Banyak orang berpikir bahwa pemasaran adalah penjualan. Bahkan masih ada perusahaanperusahaan kecil yang menganggap pemasaran itu adalah tentang penjualan. Jika perusahan-perusahaan tersebut masih selalu menganggap pemasaran itu adalah mengenai hal penjualan, maka perusahaan tersebut tidak akan dapat berkembang menjadi perusahaan yang besar.

Pemasaran adalah kegiatan yang dilakukan oleh perusahaan untuk mempromosikan suatu produk atau layanan yang mereka punya. Pemasaran ini mencakup pengiklanan, penjualan, dan pengiriman produk ke konsumen atau perusahaan lain. Dalam melakukan promosi, mereka akan menargetkan orang- orang yang sesuai dengan produk yang dipasarkan. Biasanya mereka juga melibatkan selebriti, selebgram atau siapapun yang memiliki kepopuleran untuk mendongkrak produk tersebut. Tak hanya itu, dalam pemasaran, bagian yang memiliki tugas ini akan membuat kemasan atau desain yang menarik pada iklan sehingga akan banyak orang yang tertarik.

Selain itu, dengan adanya pemasaran juga sangat membantu para konsumen. Jadi mereka akan lebih mudah menemukan produk yang sesuai dengan apa yang mereka butuhkan. Ketika pemasaran sesuai dengan targetnya, perusahaan akan mendapatkan banyak pembeli dan kefuntungan bisa didapatkan. Pengenalan menjadi fungsi utama dari sebuah pemasaran yang dilakukan oleh perusahaan. Dengan adanya pemasaran, produk akan lebih mudah dikenal oleh pelanggan. Pemasar harus menonjolkan keunggulan dari produk yang di pasarkan. Sehingga bisa lebih menarik perhatian dibanding produk pesaing (Alma, 2003).

Tingkat dan jenis kebutuhan serta keinginan konsumen itu dapat berbeda satu dengan yang lainnya, yang ini menyebabkan pilihan terhadap terbukanya usaha bisnis peluangnya menjadi semakin banyak dan besar, alasan pemilihan atau tujuan pemilihan dan faktor-faktor yang harus dipertimbangkan dalam suatu usaha berbisnis pada setiap konsumen juga berbeda. Selain itu, menentukan segmen mana pangsa pasar berada dan mengindentifikasikan konsumen ke dalam segmensegmen tertentu serta mengindentifikasi target apa yang dicapai dan positioning-nya.

Dengan adanya strategi pemasaran ini perusahaan dapat meningkatkan penjualanpenjualannya. Perusahaan tersebut dengan matang dapat mengetahui seberapa besar pangsa pasarnya. Selain itu, perusahaan dapat juga mengetahui kebutuhan konsumen berdasarkan segmen yang ada. Citra yang baik serta kepercayaan terhadap perusahaan akan membuat konsumen terpikat untuk mengadakan pembelian ulang dan konsumen tidak akan beralih pada perusahaan lain yang juga menawarkan produk yang sejenis. Bagi perusahaan hal ini akan mempermudah penentuan kebijaksanaan pemasaran yang tepat, sejalan dengan berkembangnya teknologi pada saat ini.

Persaingan yang semakin ketat dalam dunia bisnis telah merambah ke semua sektor usaha (bisnis), sehingga kompetisi yang ada antara perusahaan semakin ketat, termasuk kompetisi antara Usaha Kecil dan Menengah (UKM). UKM adalah jenis bisnis yang dijalankan dengan skala kecil dan menengah dan bukan anak perusahaan atau cabang perusahaan mana pun. Jadi secara tidak langsung pengertian UKM adalah usaha kecil memiliki pemasukan di bawah 300 juta dengan jumlah pekerja di bawah 20 orang. Sedangkan usaha menengah dengan pemasukan di bawah 500 juta dengan jumlah karyawan di bawah 30 orangm (GO UKM, 2021)

Setiap perusahaan dapat meningkatkan penjualan produknya dengan menggunakan sistem pemasaran yang efektif, serta strategi-strategi yang khusus dalam meningkatkan pasar konsumen yang ada. Strategi pemasaran tersebut adalah Strategi tentang Marketing Mix yaitu Price (harga), Product (produk), Promotion (promosi), dan Places (distribusi). Pemasaran merupakan salah satu fungsi yang sangat penting dalam perusahaan, dimana dengan pemasaran yang tepat dapat menentukan volume penjualan dan posisi perusahaan (produk) di pasar. Penguasaan pangsa 
pasar sangat tergantung kepada kemampuan untuk memanfaatkan strategi pemasaran perusahaan (Hartono, 2012).

Gambaran di atas yang berkaitan dengan kain Ulos, kota Pematangsiantar, pemasaran, strategi pemasaran serta peningkatan penjualan merupakan butir analisis yang terangkum dalam sebuah penelitian dengan judul "Analisis Upaya Strategi Pemasaran Dinas Koperasi Usaha Kecil Menengah dan Perdagangan Kota Pematangsiantar dalam Meningkatkan Hasil Penjualan Produk UKM Tenun Ulos di kota Pematangsiantar".

\subsection{Batasan Masalah}

Batasan masalah dimaksudkan untuk membatasi ruang lingkup kajian dalam penelitian. Agar permasalahan yang dikaji terarah maka permasalahan dibatasi dengan hanya mengkaji tentang bauran pemasaran yaitu produk, harga, dan promosi untuk meningkatkan hasil penjualan produk UKM Tenun Ulos di kota Pematangsiantar.

\subsection{Rumusan Masalah}

Berdasarkan latar belakang masalah dan identifikasi permasalahan sebagaimana tersebut di atas, rumusan masalah dalam penelitian ini adalah:

1) Bagaimana pengaruh strategi produk sebagai upaya strategi pemasaran Dinas Koperasi Usaha Kecil Menengah dan Perdagangan Kota Pematangsiantar dalam meningkatkan hasil penjualan produk UKM Tenun Ulos di Kota Pematangsiantar.

2) Bagaimana pengaruh harga sebagai upaya strategi pemasaran Dinas Koperasi Usaha Kecil Menengah dan Perdagangan Kota Pematangsiantar dalam meningkatkan hasil penjualan produk UKM Tenun Ulos di Kota Pematangsiantar.

3) Bagaimana pengaruh promosi sebagai Upaya Strategi Pemasaran Dinas Koperasi Usaha Kecil Menengah dan Perdagangan Kota Pematangsiantar Dalam Meningkatkan Hasil Penjualan Produk Ukm Tenun Ulos di Kota Pematangsiantar.

4) Bagaimana pengaruh produk, harga dan promosi secara bersama-sama sebagai upaya strategi pemasaran Dinas Koperasi Usaha Kecil Menengah dan Perdagangan Kota Pematangsiantar dalam meningkatkan hasil penjualan produk UKM Tenun Ulos di Kota Pematangsiantar.

\subsection{Tujuan Penelitian}

Berdasarkan rumusan masalah penelitian sebagaimana diuraikan di atas, tujuan yang hendak dicapai dalam penelitian ini yaitu:

1)__ Menganalisis pengaruh produk sebagai upaya strategi pemasaran Dinas Koperasi Usaha Kecil Menengah dan Perdagangan Kota Pematangsiantar dalam meningkatkan hasil penjualan produk UKM Tenun Ulos di Kota Pematangsiantar.

2) Menganalisis pengaruh harga sebagai upaya strategi pemasaran Dinas Koperasi Usaha Kecil Menengah dan Perdagangan Kota Pematangsiantar dalam meningkatkan hasil penjualan produk UKM Tenun Ulos di Kota Pematangsiantar.

3) Menganalisis pengaruh promosi sebagai Upaya Strategi Pemasaran Dinas Koperasi Usaha Kecil Menengah dan Perdagangan Kota Pematangsiantar Dalam Meningkatkan Hasil Penjualan Produk Ukm Tenun Ulos di Kota Pematangsiantar.

4) Menganalisis pengaruh produk, harga dan promosi secara bersama-sama sebagai upaya strategi pemasaran Dinas Koperasi Usaha Kecil Menengah dan Perdagangan Kota Pematangsiantar dalam meningkatkan hasil penjualan produk UKM Tenun Ulos di Kota Pematangsiantar.

\subsection{Hipotesis}

Hipotesis pada penelitian ini dapat dirumuskan sebagai berikut:

1). Ada pengaruh strategi produk sebagai upaya strategi pemasaran Dinas Koperasi Usaha Kecil Menengah dan Perdagangan Kota Pematangsiantar dalam meningkatkan hasil penjualan produk UKM Tenun Ulos di Kota Pematangsiantar.

2) Ada pengaruh harga sebagai upaya strategi pemasaran Dinas Koperasi Usaha Kecil Menengah dan Perdagangan Kota Pematangsiantar dalam meningkatkan hasil penjualan produk UKM Tenun Ulos di Kota Pematangsiantar.

3) Ada pengaruh promosi sebagai Upaya Strategi Pemasaran Dinas Koperasi Usaha Kecil Menengah dan Perdagangan Kota Pematangsiantar Dalam Meningkatkan Hasil Penjualan Produk Ukm Tenun Ulos di Kota Pematangsiantar.

\section{Metode Penelitian}

\subsection{Populasi}


Menurut Manullang dan Pakpahan (2014), populasi adalah suatu kelompok dari elemen penelitian, dimana elemen adalah unti terkecil yang merupakan sumber data yang diperlukan. Elemen dapat dianalogikan sebagai unit analisis, sepanjang pengumpulan data penelitian dilakukan hanya kepada responden.

Populasi dari penelitian ini adalah para konsumen yang datang dan melihat produk di Usaha Mikro, Kecil dan Menengan Tenun Ulos Binaan Dinas Koperasi, UKM, dan Perdagangan Kota Pematangsiantar. Populasi dalam penelitian ini tidak terdeteksi jumlahnya, tetapi dengan melakukan riset selama 14 hari dimana rata-rata pelanggan atau konsumen yang datang berbelanja adalah 20 orang. Maka populasi dari penelitian ini 14 hari x 20 orang adalah 280 orang.

\subsection{Sampel}

Menurut Manullang dan Pakpahan (2014), sampel adalah bagian dari populasi yang diharapkan dapat mewakili penelitian. Penentuan sampel responden yang di gunakan dalam penelitian ini adalah non probability sampling dengan pendekatan accidental sampling yaitu objek yang kebetulan bertemu pada saat pengumpulan data, dan sesuai untuk diteliti maka dijadikan sebagai sampel penelitian.

Berdasarkan hasil perhitungan dengan slovin, maka jumlah sampel yang digunakan adalah 73,6 responden. Dan setelah dibulatkan menjadi 74 responden. Jadi, jumlah sampel yang akan dipakai dalam penelitian ini adalah berjumlah 74 responden.

Dalam penelitian ini pertimbangan dan kriteria yang dapat menjadi sampel adalah :

a. Konsumen yang mengenal dan mengetahui Usaha Mikro, Kecil dan Menengan Tenun Ulos Binaan Dinas Koperasi, UKM, dan Perdagangan Kota Pematangsiantar.

Tabel 2. Hasil Uji Validitas Variabel Produk(X1)

\begin{tabular}{|r|c|c|c|}
\hline Nomor Soal & rhitung & rtabel & Keterangan \\
\hline 1 & 0,683 & 0,229 & Valid \\
\hline 2 & 0,697 & 0,229 & Valid \\
\hline 3 & 0,624 & 0,229 & Valid \\
\hline 4 & 0,585 & 0,229 & Valid \\
\hline 5 & 0,530 & 0,229 & Valid \\
\hline 6 & 0,505 & 0,229 & Valid \\
\hline 7 & 0,651 & 0,229 & Valid \\
\hline 8 & 0,623 & $N 0,229$ & Valid \\
\hline 9 & 0,564 & 0,229 & Valid \\
\hline 10 & 0,645 & 0,229 & \\
\hline
\end{tabular}


Tabel 3 Hasil Uji Validitas Variabel Harga (X2)

\begin{tabular}{|c|c|c|c|}
\hline Nomor Soal & rhitung & rtabel & Keterangan \\
\hline 1 & 0,640 & 0,229 & Valid \\
\hline 2 & 0,692 & 0,229 & Valid \\
\hline 3 & 0,729 & 0,229 & Valid \\
\hline 4 & 0,796 & 0,229 & Valid \\
\hline 5 & 0,667 & 0,229 & Valid \\
\hline 6 & 0,656 & 0,229 & Valid \\
\hline 7 & 0,888 & 0,229 & Valid \\
\hline 8 & 0,761 & 0,229 & Valid \\
\hline 9 & 0,724 & 0,229 & Valid \\
\hline 10 & 0,513 & 0,229 & \\
\hline
\end{tabular}

Tabel 4. Hasil Uji Validitas Variabel Promosi (X3)

\begin{tabular}{|r|c|c|c|}
\hline Nomor Soal & rhitung & rtabel & Keterangan \\
\hline 1 & 0,408 & 0,229 & Valid \\
\hline 2 & 0,592 & 0,229 & Valid \\
\hline 3 & 0,852 & 0,229 & Valid \\
\hline 4 & 0,876 & 0,229 & Valid \\
\hline 5 & 0,849 & 0,229 & Valid \\
\hline 6 & 0,832 & 0,229 & Valid \\
\hline 7 & 0,835 & 0,229 & Valid \\
\hline 8 & 0,796 & 0,229 & Valid \\
\hline 9 & 0,784 & 0,229 & Valid \\
\hline 10 & 0,473 & 0,229 & Valid \\
\hline
\end{tabular}

Tabel 5. Hasil Uji Validitas Variabel Hasil Penjualan(Y)

\begin{tabular}{|c|c|c|c|}
\hline Nomor Soal & rhitung & rtabel & Keterangan \\
\hline 1 & 0,606 & 0,229 & Valid \\
\hline 2 & 0,590 & 0,229 & Valid \\
\hline 3 & 0,515 & 0,229 & Valid \\
\hline 4 & 0,615 & 0,229 & Valid \\
\hline 5 & 0,556 & 0,229 & Valid \\
\hline 6 & 0,745 & 0,229 & Valid \\
\hline 7 & 0,736 & 0,229 & Valid \\
\hline 8 & 0,788 & 0,229 & Valid \\
\hline 9 & 0,476 & 0,229 & Valid \\
\hline 10 & 0,667 & 0,229 & \\
\hline
\end{tabular}

Rekapitulasi Validitas variabel dependen dan independen yang terdapat pada tabel 5.6 hingga 5.9 tersebut di atas seluruh pernyataan dalam setiap variabel memiliki nilai Corrected Item Correlation (rhitung) lebih besar dari rtabel. Dengan demikian, dapat dikatakan bahwa setiap butir pernyataan adalah valid sehingga penelitian ini dapat diteruskan dalam pengujian reliabilitas.

\subsubsection{Uji Reliabilitas Data}

Pada penelitian ini, uji reliabilitas menggunakan metode Cronbach Alpha. Reliabilitas diukur dengan menguji tingkat konsistensi hasil pengukuran jika dilakukan pengukuran ulang. Andal atau tidaknya suatu data dapat dilihat dari koefisien alpha yang dihasilkan, data yang mendekati angka 1 (satu) dapat dikatakan memiliki keandalan tinggi. Nilai koefisien Cronbach Alpha 
yang mendekati 1 menunjukkan bahwa hasil yang diperolehsemakin konsisten sehingga dikatakan mempunyai reliabilitas yang tinggi. Suatu data dikatakan akurat jika nilai koefisien cronbach alpha minimum adalah 0,60. Uji reliabilitas pada penelitian ini menggunakan program SPSS versi 20.0 .

Table 6 Hasil Uji Reabilitas

\begin{tabular}{|r|c|c|c|}
\hline Variable & $\begin{array}{c}\text { Cronbach's } \\
\text { Alpha }\end{array}$ & N of Items & $\begin{array}{c}\text { Reabilitas } \\
\text { Status }\end{array}$ \\
\hline X1 &, 813 & 10 & Reliabel \\
\hline X2 &, 891 & 10 & Reliabel \\
\hline X3 &, 908 & 10 & Reliabel \\
\hline Y &, 826 & 10 & Reliabel \\
\hline
\end{tabular}

Sumber: Data diolah-2021

Hasil uji reliabilitas yang dilakukan terhadap variabel dependen dan independen seperti tertera pada tabel 5.10 di atas, terlihat bahwa nilai Cronbach Alpha seluruh variabel berkisar antara 0 sampai 1 dan lebih cenderung mendekati angka 1 . Dengan demikian keseluruhan item dalam instrumen pengukuran dapat kategorikan sangat reliabel.

\subsection{Uji Asumsi Klasik}

\subsubsection{Uji Normalitas Data}

Pengujian normalitas data bertujuan untuk melihat normal tidaknya sebaran data yang akan dianalisis. Model regresi yang baik adalah distribusi normal atau mendekati normal. Untuk melihat normalitas data ini digunakan pendekatan grafik yaitu Normality Probability Plot. Deteksi normalitas dengan melihat penyebaran data (titik) pada sumbu diagonal dari grafik. dasar hasil Penjualan (Santoso, 2004: 214), adalah:

a. Jika data menyebar disekitar garis diagonal dan mengikuti arah garis diagonal, maka model regresi memenuhi asumsi normalitas.

b. Jika data menyebar jauh dari garis diagonal dan atau tidak mengikuti arah garis diagonal, maka model regresi tidak memenuhi asumsi normalitas.

Pada output SPSS bagian normal P-P Plot of Regresion Standardized Residual, dapat dijelaskan bahwa data-data (titik-titik) cenderung lurus mengikuti garis diagonal sehingga data dalam penelitian ini cenderung berdistribusi normal, seperti terlihat pada gambar di bawah ini.

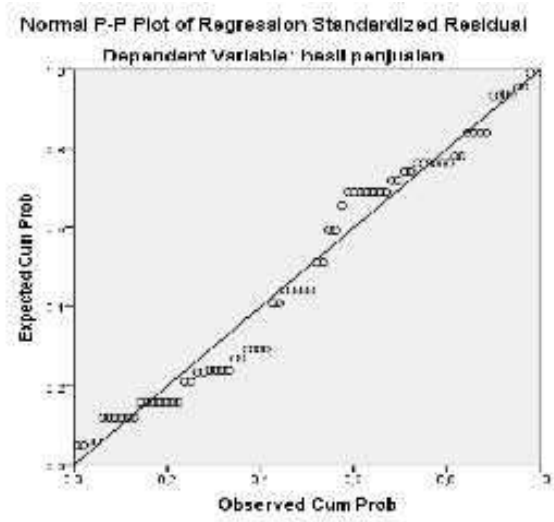

Gambar 1. Normalitas Data ((Sumber: Out Put SPSS Data Diolah-2021)

\subsubsection{Uji Multikolinearitas}

Pengujian multikolinearitas dilakukan untuk melihat apakah pada model regresi ditemukan adanya korelasi antara variabel bebas. Jika terjadi korelasi, maka dinamakan terdapat problem multikolinearitas. Cara mendeteksinya adalah dengan melihat nilai Variance Inflation Factor (VIF). Menurut Santoso (2014:203), pada umumnya jika VIF lebih besar dari 5, maka variabel bebas tersebut mempunyai persoalan multikolinearitas dengan variabel bebas lainnya. Pada ouput SPSS bagian Coefficient, semua angka VIF berada di bawah 5, hal ini menunjukan tidak terjadi multikolinearitas, seperti dapat dilihat pada tabel 5.10.

Tabel 7. Uji Multikolinearitas Coefficients

\begin{tabular}{|c|c|c|c|}
\hline \multicolumn{2}{|c|}{ Model } & \multicolumn{2}{|c|}{\begin{tabular}{|c} 
Collinearity \\
Statistics \\
Tolerance VIF
\end{tabular}} \\
\hline \multirow{4}{*}{1} & (Constant) & & \\
\hline & strategi.produk & ,653 & 1,530 \\
\hline & strategi.harga & ,760 & 1,315 \\
\hline & strategi.promosi & ,784 & 1,275 \\
\hline
\end{tabular}

\subsubsection{Uji Heteroskedastisitas}

Pengujian heteroskedastisitas bertujuan untuk melihat apakah dalam sebuah model regresi terjadi ketidaksamaan varians dari residual yang merupakan suatu pengamatan ke pengamatan yang lainnya. Jika varians dari residual yang merupakan suatu pengamatan ke pengamatan yang lain bernilai tetap, maka hasil data disebut homoskedastisitas dan jika varians berbeda atau bernilai tidak tetap maka disebut heteroskedastisitas. Model regresi yang baik 
adalah model yang bernilai tetap atau homoskedastisitas atau tidak terjadi heteroskedastisitas.

Deteksi heteroskedastisitas dilakukan dengan cara melihat ada tidaknya pola tertentu pada data yang diolah. Menurut Santoso (2014: 208), dasar hasil Penjualannya adalah:

a. Jika pola tertentu seperti titik-titik yang ada membentuk suatu pola tertentu yang teratur, maka terdapat situasi heteroskedastisitas.

b. Jika tidak ada pola yang jelas, serta titiktitik menyebar di atas dan di bawah angka nol pada sumbu Y, maka tidak terjadi heteroskedastisitas. Pada output SPSS dibagian Scatrerplot, terlihat titk-titik menyebar secara acak, tidak membentuk sebuah pola tertentu yang jelas, serta tersebar baik di atas maupun di bawah angka nol pada sumbu Y. Hal ini berarti tidak terjadi heterskedastisitas pada model regresi, sehingga model regresi layak dipakai. Pola Scatterplot dapat dilihat pada gambar di bawah ini.

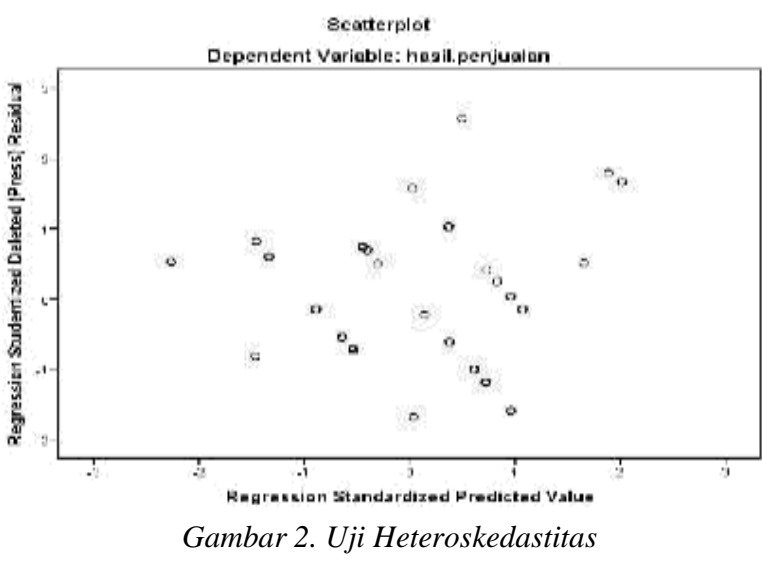

\subsection{Evaluasi Data}

\subsubsection{Pengujian Hipotesis}

Dalam evaluasi data ini penulis akan melakukan pengujian hipotesis, baik secara partial ataupun secara simultan. Selanjutnya untuk mempermudah dalam evaluasi data ini, maka penulis mencari niali-nilai yang dibutuhkan dengan menggunakan perangkat lunak komputer yaitu program SPSS V.20.00 for windows dengan hasil data sebagai berikut:

Tabel 8 Hasil Uji Statistik Koefisien Regresi

Coefficients ${ }^{\mathbf{a}}$

\begin{tabular}{|c|c|c|c|c|c|c|}
\hline \multirow{2}{*}{\multicolumn{2}{|c|}{ Model }} & \multicolumn{2}{|c|}{$\begin{array}{l}\text { Unstandardized } \\
\text { Coefficients }\end{array}$} & \multirow{2}{*}{$\begin{array}{c}\text { Standardized } \\
\text { Coefficients }\end{array}$} & \multirow[t]{2}{*}{$\mathrm{t}$} & \multirow[t]{2}{*}{ Sig. } \\
\hline & & B & Std. & & & \\
\hline \multirow{4}{*}{1} & (Constant) & 4,616 & 3,596 & & 1,284 & ,203 \\
\hline & strategi.produk & ,354 & ,052 &, 523 & 6,853 &, 000 \\
\hline & strategi.harga & ,242 & ,069 & ,249 & 3,522 & ,001 \\
\hline & strategi.promosi & ,345 & ,081 & ,295 & 4,238 & ,000 \\
\hline
\end{tabular}

Sumber: Out Put SPSS Data Diolah-2021

Dari tabel 8 di atas dapat dibuat persamaan regresi sebagai berikut:

$$
Y=3,596+0,354 X 1+0,242 X 2+0,345 X 3+\varepsilon .
$$

Dari persamaan tersebut dijelaskan bahwa koefesien X1 (Produk) mempunyai nilai positif yaitu 0,354 , hal ini menunjukan bahwa variabel Produk mempunyai pengaruh positif terhadap variabel Hasil Penjualan. Koefesien X2 (Harga) memiliki nilai positif yaitu 0,242. Hal ini menunjukan bahwa variabel Harga mempunyai pengaruh positif terhadap variabel Hasil Penjualan. Koefesien X3 (Promosi) juga memiliki nilai positif yaitu 0,345 . Hal ini menunjukan bahwa variabel Promosi juga mempunyai pengaruh positif terhadap varibel Hasil Penjualan.

\subsubsection{Pengujian Secara Simultan (Uji F)}

Hasil pengujian hipotesis secara simultan antara Produk, Harga, dan Promosi terhadap Hasil Penjualan di Dinas Koperasi Usaha Kecil Menengah dan Perdagangan Kota Pematangsiantar dapat dilihat pada tabel di bawah ini. 
Tabel 9 Hasil Uji Statistik Secara Simultan

ANOVA ${ }^{a}$

\begin{tabular}{|l|l|r|r|r|r|c|}
\hline \multicolumn{1}{|l|}{ Model } & Sum of Squares & df & Mean Square & F & Sig. \\
\hline \multirow{3}{*}{1} & Regression & 76,272 & 3 & 25,424 & 64,183 &, $000 \mathrm{~b}$ \\
\cline { 2 - 8 } & Residual & 27,728 & 70 &, 396 & & \\
\cline { 2 - 8 } & Total & 104,000 & 73 & & & \\
\hline
\end{tabular}

a. Dependent Variable: Hasil.penjualan

b. Predictors: (Constant), Promosi, Harga, Produk

Sumber: Out Put SPSS Data Diolah-2021

Dari tabel 9 di atas dapat diketahui denngan jelas bahwa nilai Fhitung adalah 64,183 dan nilai signifikansi 0,000. Diketahui nilai Ftabel dengan tingkat kepercayaan 95\% $(\alpha: 0,05)$ adalah 2,740. Oleh karena itu nilai Fhitung> Ftabel (31,734 > 2,740 maka $\mathrm{H}_{\mathrm{O}}$ ditolak dan menerima hipotesis dalam penelitian ini yaitu bahwa Produk,, Harga, dan promosi berpengaruh positif dan signifikan terhadap Hasil Penjualan di Dinas Koperasi Usaha Kecil Menengah dan Perdagangan Kota Pematangsiantar.

\subsubsection{Pengujian Secara Parsial (Uji t)}

Tabel 10 Hasil Uji Parsial Variabel X Terhadap Y

Coefficientsa

\begin{tabular}{|c|c|c|c|c|c|c|}
\hline \multirow{2}{*}{\multicolumn{2}{|c|}{ Model }} & \multicolumn{2}{|c|}{$\begin{array}{c}\text { Unstandardized } \\
\text { Coefficients }\end{array}$} & \multirow{2}{*}{$\begin{array}{c}\begin{array}{c}\text { Standardized } \\
\text { Coefficients }\end{array} \\
\text { Beta }\end{array}$} & \multirow[t]{2}{*}{$\mathrm{t}$} & \multirow[t]{2}{*}{ Sig. } \\
\hline & & B & Std. & & & \\
\hline \multirow{4}{*}{1} & (Constant) & 4,616 & 3,596 & & 1,284 & ,203 \\
\hline & strategi.produk &, 354 & ,052 & ,523 & 6,853 & ,000 \\
\hline & strategi.harga & ,242 & ,069 & ,249 & 3,522 & ,001 \\
\hline & strategi.promosi & ,345 & ,081 & ,295 & 4,238 & ,000 \\
\hline
\end{tabular}

\subsubsection{Pengaruh X1 terhadap Y}

Secara parsial pengaruh Produk (X1) terhadap Hasil Penjualan (Y) dapat diketahui dengan memperhatikan data pada tabel 5.14 di atas. Berdasarkan tabel tersebut diperoleh nilai thitung sebesar 6,853 dan nilai signifikansi 0,000 . Sedangkan nilai tabel pada tingkat kepercayaan $95 \%(\alpha: 0,05)$ adalah 2,000. Oleh karena itu nilai thitung > tabel $(6,853>2,000)$ maka Ho ditolak dan menerima hipotesis dalam penelitian ini yaitu variabel Produk berpengaruh positif terhadap Hasil Penjualan di Dinas Koperasi Usaha Kecil Menengah dan Perdagangan Kota Pematangsiantar.

\subsubsection{Pengaruh X2 terhadap $Y$}

Secara parsial pengaruh Harga (X2) terhadap Hasil Penjualan (Y) dapat dilihat pada tebel 5.14 di atas. Berdasarkan tabel tersebut diperoleh nilai thitung sebesar 3,522 dan nilai signifikansi 0,001 . Sedangkan nilai ttabel pada tingkat kepercayaan 95\% $(\alpha: 0,05)$ adalah 2,000. Oleh karena itu nilai thitung > ttabel $(3,522>2,000)$ maka $\mathrm{H}_{\mathrm{O}}$ ditolak dan menerima hipotesis dalam penelitian ini yaitu Harga berpengaruh positif terhadap Hasil Penjualan di Dinas Koperasi Usaha Kecil Menengah dan Perdagangan Kota Pematangsiantar.

\subsubsection{Pengaruh X3 terhadap Y}

Untuk mengetahui secara parsial pengaruh promosi (X3) terhadap Hasil Penjualan (Y) dapat dilihat pada tebel 5.14 di atas. Berdasarkan tabel tersebut diperoleh nilai thitung sebesar 4,238 dan nilai signifikansi 0,001 . Sedangkan nilai ttabel pada tingkat kepercayaan 95\% ( $\alpha$ : $0,05)$ adalah 2,000. Oleh karena itu nilai thitung $>$ ttabel $(4,238>2,000)$ maka $\mathrm{Ho}_{\mathrm{o}}$ ditolak dan menerima hipotesis dalam penelitian ini yaitu variabel Promosi berpengaruh positif terhadap Hasil Penjualan di Dinas Koperasi Usaha Kecil Menengah dan Perdagangan Kota Pematangsiantar. 


\subsubsection{Uji Koefisien Determinasi $\left(\mathbf{R}^{\mathbf{2}}\right)$}

Uji determinan digunakan untuk mengetahui seberapa besar pengaruh variabel independen terhadap variabel dependen. Untuk melihat hasil uji determinan maka dapat diketahui nilai $\mathrm{R}$ Square atau koefesien determinasi dapat dilihat di bawah ini.

Tabel 11 Model Summary

Model Summaryb

\begin{tabular}{|c|c|c|c|c|c|c|}
\hline \multirow[t]{2}{*}{ Model } & \multirow[t]{2}{*}{$\mathrm{R}$} & \multirow[t]{2}{*}{ R Square } & \multirow{2}{*}{$\begin{array}{l}\text { Adjusted R } \\
\text { Square }\end{array}$} & \multirow{2}{*}{$\begin{array}{l}\text { Std. Error of } \\
\text { the Estimate }\end{array}$} & \multicolumn{2}{|c|}{ Change Statistics } \\
\hline & & & & & R Square Change & F Change \\
\hline 1 &, $856^{\mathrm{a}}$ &, 733 &, 722 & ,62938 & ,733 & 64,183 \\
\hline
\end{tabular}

Pada tabel di atas dapat diketahui bahwa Nilai $R$ Square adalah 0,733. Hal ini menunjukan bahwa 73,30\% variabel Hasil Penjualan di Dinas Koperasi Usaha Kecil Menengah dan Perdagangan Kota Pematangsiantar dapat dijelaskan oleh variabel Produk, Harga, dan Promosi sedangkan sisanya sebesar $26,70 \%$ tidak dilakukan penelitian.

\section{Kesimpulan}

Dari hasil uji yang dilakukan dapat disimpulkan bahwa:

1. Variabel produk, harga dan promosi secara parsial atau sendiri-sendiri berpengaruh positif dan signifikan terhadap hasil penjualan hasil penjualan UKM Tenun Ulos di Kota Pematangsiantar. Variabel Produk memiliki nilai thitung sebesar 6,853 dan signifikansi 0,000 . Variabel harga memiliki nilai thitung sebesar 3,522 dan signifikansi 0,001 dan promosi memiliki nilai thitung sebesar 4,238 dan signifikansi 0,001 .

2. Pengujian yang dilakukan terhadap variabel produk, harga dan promosi secara bersamasama atau simultan berpengaruh positif dan signifikan terhadap hasil penjualan hasil penjualan UKM Tenun Ulos di Kota Pematangsiantar dengan nilai sebesar 64,183 dan signifikansi level 0,000.

3. Nilai $\mathrm{R}$ Square adalah 0,733. Hal ini menunjukan bahwa $73,30 \%$ variabel Hasil Penjualan di Dinas Koperasi Usaha Kecil Menengah dan Perdagangan Kota Pematangsiantar dapat dijelaskan oleh variabel Produk, Harga, dan Promosi sedangkan sisanya sebesar $26,70 \%$ tidak dilakukan penelitian.

\section{DAFTAR PUSTAKA}

Alamiyah dan Padji. 2003. Kamus Istilah Akuntansi. Cetakan Kesatu. Bandung: Yrama Widya

Alma, B. 2003. Manajemen Pemasaran dan Pemasaran Jasa. Edisi 2.

Bandung: ALFABETA

Assauri, Sofjan. 2013. Manajemen Pemasaran. Jakarta : Rajawali Pers

Aziz, Abdul dan Asymar Syaid. 2016. Pengaruh Harga, Promosi Penjualan, dan Proses (Pelayananan) Terhadap Kepuasan Konsumen Di Kedai EYCKMAN. http://repository.unpas.ac.id/id/eprint/14389.

Badan Pusat Statistik Kota Pematangsiantar. 2019. Jumlah Penduduk Kota Pematangsiantar Per Kecamatan 2010-2018. Tersedia di: https://siantarkota.bps.go.id/dynamictable/2015/ 09/25/2/jumlah- penduduk pematangsiantar-perkecamatan-2010-2018.html

Basu, Swastha dan Irawan. 2003. Manajemen Pemasaran Modern. Yogyakarta: Liberty.

Basu, Swastha. 2002. Manajemen Penjualan. Yogyakarta: Liberty.

Basu, Swastha. 2007. Manajemen Pemasaran Analisa Perilaku Konsumen.

Yogyakarta: BPFE

Christiani, Situmorang dan Suryawan, Ida Bagus. 2017. Daya Tarik Wisata Unggulan Di Daerah Transit Kota Pematangsiantar, Sumatera Utara. Jurnal Destinasi Pariwisata.

\section{Daryanto, Danang 2011. Manajemen}

Pemasaran: Sari Kuliah. Cetakan I.

Bandung: Satu Nusa

Diniaty, Dewi dan Agusrinal. 2014. Perancangan Strategi Pemasaran Pada Produk Anyaman Pandan (Studi Kasus: Home Industry Saiyo Sakato Di Kenagarian Padang Laweh 
Kecamatan Koto VII Kabupaten Sawahlunto Sijunjung). Jurnal Sains, Teknologi dan Industri, Vol. 11, No. 2, Juni

2014, pp. $175-184$.

Diniaty, Dewi. 2019. Analisis Strategi Pemasaran dalam Upaya Meningkatkan Penjualan Ikan Salai Patin pada Kelompok XYZ. JKBM (Jurnal Konsep Bisnis dan Manajemen) Vol 6 (1) November 2019

Firmando, Harisan Boni. 2020. Strategi Adaptasi Pemasaran Kerajinan Tenun Ulos Pada Pasar Tradisional, Modern Dan On Line Di Tapanuli Utara (Studi di Kota Tarutung). AT-TAWASSUTH: Jurnal Ekonomi Islam, Vol. V, No. 1. DOI: http://dx.doi.org/10.30821/ajei.v5i1.7674

GO UKM. 2021. Pengertian UKM \& UMKM? Bagaimana Menjadi Usaha Kecil Menengah di Indonesia. https://goukm.id/apa-itu-ukmumkm- startup/.

Hartono, Hendry, dkk. 2012. Pengaruh Strategi Pemasaran Terhadap Peningkatan Penjualan Pada perusahaan Dengan Menetapkan Alumni Dan Mahasiswa Universitas Bina Nusantara Sebagai Objek Penelitian.

BUSINESS

REVIEW.

https://media.neliti.com/media/publications/167 985-ID-pengaruh-strategi- pemasaran-terhadappen.pdf.

Jasmani. 2018. Pengaruh Promosi Dan Pengembangan Produk Terhadap Peningkatan Hasil Penjualan (Studi PT. Baja Perkasa Jakarta). Jurnal Semarak, Vol. 1, No.3, Oktober 2018, Hal (142-157)

Karim, Djamaluddin, J.L. Sepang dan B. Lumanauw. 2014. Marketing Mix Pengaruhnya Terhadap Volume Penjualan, Jurnal Emba Volume 2, Nomor 1, Maret 2014, 423

Kotler dan Amstrong. 2008. Prinsip-prinsip Pemasaran. Jilid 1 dan 2. Edisi 12.

Jakarta: Erlangga.

Kotler, Philip and Garry Amstrong. 2012. Principles of Marketing. New Jersey: Pearson Education Limited. Jurnal Riset Manajemen Sains Indonesia (JRMSI) |Vol. 3, No. 1, 2012.

Kotler, Philip. 2010. Manajemen Pemasaran. Edisi tiga belas Bahasa Indonesia.Jilid 1 dan 2. Jakarta: Erlangga.

Kotler. 2014, Manajemen Pemasaran, Edisi Keempat belas, PT. Indeks, Jakarta.

Kusdiana, Dikdik dan Ardi Gunardi. 2014. Pengembangan Produk Unggulan UMKM Kabupaten Sukabumi. Jurnal Trikonomika. Vol. 13, No.2:
153-171

Ma'ruf, Hendri. 2005. Pemasaran Ritel. (Cetakan pertama). Jakarta: PT Gramedia Pustaka Utama.

Prasetijo, Ristiyanti dan John J.O.I Ihalauw. 2005. Perilaku Konsumen. Yogyakarta: ANDI.

Purba, M.D. 1977. Mengenal Kepribadian Asli Rakyat Simalungun. Medan: M.D. Purba.

Rachmawati, Rina. 2011. Strategi Pemasaran Untuk Meningkatkan Volume

Penjualan. Jurnal Kompetensi Teknik. Vol.2, No. 2, Mei 2011, 144.

Rusdi, Moh. 2019. Strategi Pemasaran Untuk Meningkatkan Volume Penjualan Pada Perusahaan Genting Ud. Berkah Jaya. JSMB (Jurnal Studi Manajemen dan Bisnis) Vol. 6 (2) 2019 hlm. 49-54.

Schiffman dan Kanuk, Amelia. 2004. Analisa Marketing Mix, Lingkungan Sosial, Psikologi Terhadap Keputusan Pembelian Online Pakaian Wanita. Juarnal Manajemen Pemasaran Petra.Vol. 1, No. 2.

Simamora, Henry. 2002. Akuntansi Manajemen. Jakarta, Indonesia: Salemba Empat.

Singh, et al., 2008. Strategy Development by SMEs for Competitiveness: A Review. Benchmarking: An International Journal. Vol. 15, No.5: 525-547.

Sugiyono. 2017. Metode Penelitian Kuantitatif Kualitatif dan $\quad R \quad \& \quad$ D. Penerbit CV. Alfabeta. Bandung.

Sumodiningrat. 2011. Pengantar Statistika. Jakarta: Penerbit Andi

Susanto, Christian. 2004. Citra Merek, Kualitas Produk, dan Promosi Pengaruhnya Terhadap Kepuasan Konsumen pada Makanan Tradisional. Jurnal EMBA. Vol. 1, No. 3, September.

Sutisna. 2003. Perilaku Konsumen Dan Komunikasi Pemasaran. Bandung: PT. Remaja Rosdakarya,

Tambunan, Tulus. 2012. Usaha Mikro, Kecil dan Menengah di Indonesia: Isu-Isu Penting. Jakarta: LP3ES

Tjiptono, Fandy. 2008. Strategi Pemasaran. Yogyakarta: Penerbit Andi

Wibowo, Dimas Hendika, Zainul Arifin dan Sunarti. 2015. Analisis Strategi Pemasaran Untuk eningkatkan Daya Saing UMKM (Studi pada Batik Diajeng Solo). Jurnal Administrasi Bisnis (JAB)|Vol. 29 No.1 Desember 2015|, 59-67. 